Revista de Derecho

\title{
Cómics, memoria y procesos masivos de violación de derechos. Una breve visita a Iberoamérica
}

Comics, memory and massive process of human rights violations. A brief review of Ibero-America

\author{
Danilo Caicedo Tapia \\ Corte Constitucional del Ecuador \\ danct242@gmail.com
}

DOI: https://doi.org/10.32719/26312484.2019.31.2

Fecha de recepción: 29 de marzo de 2018

Fecha de aprobación: 26 de febrero de 2019 


\section{RESUMEN}

Este artículo explora los conceptos de arte y memoria; a través de ellos se destaca su importancia, relación mutua y contenido social. Partiendo de lo anterior se realiza una exploración cualitativa mediante el cómic o historieta a la memoria de varios procesos masivos de violaciones de derechos humanos, ocurridos durante la represión vivida en Centroamérica y América del Sur entre las décadas de los años cincuenta y noventa del siglo XX, y en España con la Guerra Civil y la dictadura franquista.

El objeto de este estudio es destacar el papel ético y estético que desempeña el arte del cómic respecto a los derechos humanos, especialmente a los derechos de las víctimas a la verdad, justicia y reparación. Concluyo señalando como principales hallazgos que el cómic es una manifestación cultural, expresión artística y medio de masas que contribuye de manera efectiva a la preservación y la construcción de la memoria e incluso su potencialidad como narrativa para resistir y rebatir la historia y verdades oficiales.

PALABRAS CLAVE: arte, cómic, historieta, memoria, derechos humanos, Iberoamérica.

\section{ABSTRACT}

This article explores the concepts of art and memory. Through them its importance, mutual relationship and social content are highlighted. Starting from the above, it makes a qualitative exploration, through the comic or comic strip, of the memory of several massive processes of human rights violations, occurred during the repression lived in Central America and South America between the decades of the fifties and nineties of the twentieth century, and in Spain with the Civil War and Franco's dictatorship.

The purpose of this study is to highlight the ethical and aesthetic role played by the comic art with respect to human rights, especially regarding the rights of victims to truth, justice and reparation. I conclude by pointing out as main findings that the comic is a cultural manifestation, artistic expression and mass media that contributes effectively to the preservation and construction of memory and even its potential as a narrative to resist and refute history and official truths.

KEYWORDS: Art, comics, cartoon, memory, human rights, Ibero-America.

\section{ACERCA DE LA CONCEPTUALIZACIÓN DEL ARTE}

¿Q ué relación y relevancia podrían tener el arte y el cómic con la memoria? Empezaré a responder la pregunta de la siguiente manera; cada vez que veo el rostro de Juan Salvo, El Eternauta, un hombre de familia y un combativo argentino, 
siento y pienso lo que ha vivido dentro de su historia de ficción, también rememoro y recapacito lo que le ocurrió a su autor Héctor Germán Oesterheld, en su lucha ideológica y armada contra la represión institucionalizada en la Argentina, proceso que no se diferencia demasiado de otros contextos vividos en Iberoamérica en el siglo XX.

Viñeta 1. El Eternauta

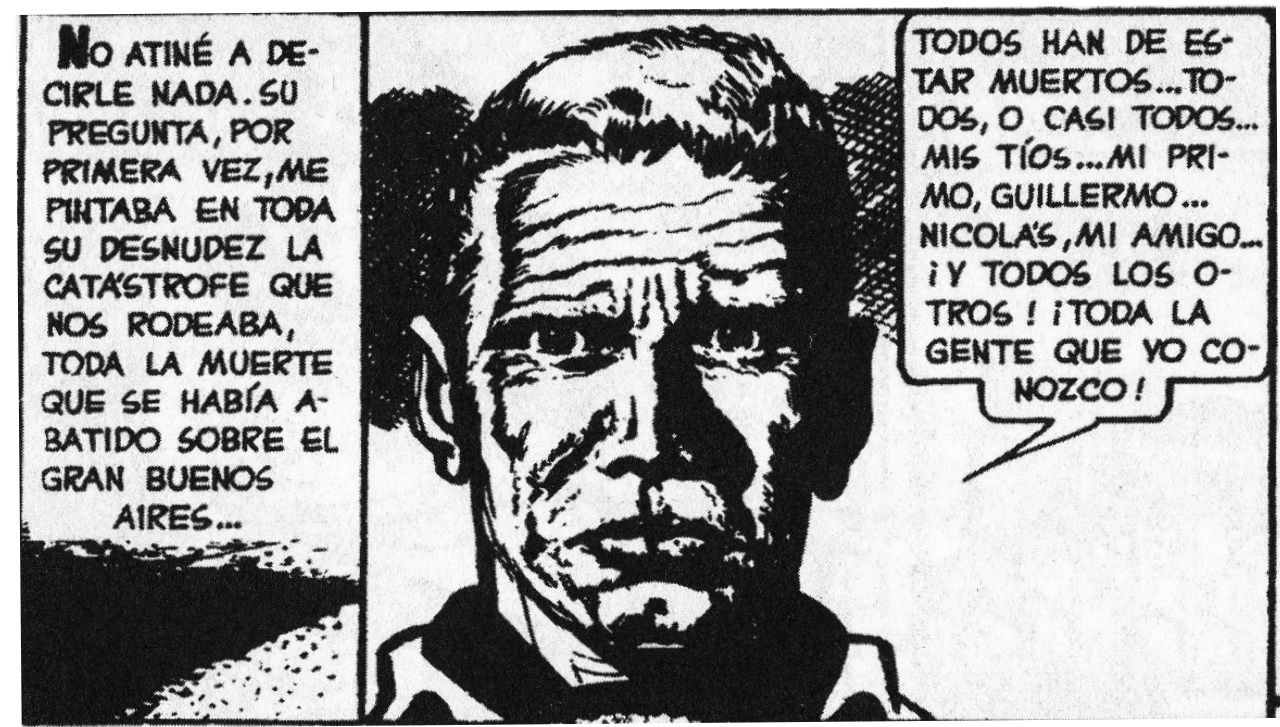

Fuente: Héctor Germán Oesterheld y Francisco Solano López, El Eternauta. Primera parte (Barcelona: RM, 2013 [1957]), 10.

Abordaré la conceptualización de dos elementos relacionados, arte y memoria; comenzaré por el primero. Existen diversas formas de entender al arte, pero acudiendo a un alto grado de simplificación podrían ser agrupadas en dos posturas. A la primera por falta de un mejor nombre la denominaré tradicional. En esta visión son consideradas obras de arte tan solo un reducido número de representaciones artísticas que han alcanzado un grado superlativo considerado sublime; así también, muy pocas personas serán apreciadas como auténticas artistas, pues no todo individuo logrará alcanzar la maestría de la técnica y el dominio de la estética requerido por los críticos expertos que interpretan y categorizan las obras. ${ }^{1}$

En esta postura el arte es un concepto racional, neutro y aséptico; la grandeza de las obras de arte radica en el cumplimiento sobresaliente de ciertos criterios estéticos.

1. Harold Bloom, Anatomía de la Influencia. La literatura como modo de vida (Madrid: Taurus, 2011), 20-52. 
Nada importa aquí el pensar y el sentir del artista, su ideología o lo que él o sus obras representan y provocan socialmente. En otras palabras, el artista y la sociedad corren por sendas separadas. Poco a poco se forma un canon de lo artístico que debe ser seguido y apreciado. No sobra decir que tanto quienes elaboran dicho canon como quienes conforman parte del selecto listado, suelen reunir las siguientes características: hombres, occidentales, blancos o mestizos, heterosexuales de mediana o avanzada edad. $^{2}$

La segunda postura de entender el arte puede ser designada, con cierta arbitrariedad, como posmoderna. En esta visión el arte tiene relación con la estética, pero no se reduce solamente a ella, cobran significancia conceptos como ideología y crítica, razón y emoción, encuentro, diálogo y democracia, libertad y subversión ante los convencionalismos y límites socialmente establecidos.

Las obras de arte en constante dinamismo serán consideradas como tales no por la sentencia dictada por un experto, sino como producto de la relación y apreciación social. En otras palabras, el arte es una construcción social. Aquí las obras de arte no son dadas de una vez y para siempre, son un punto de partida y de encuentro. Importa mucho la relación entre artista y espectador. La creación del arte en mayor o menor medida ocurre dentro de este contacto; aquí el artista es concebido como parte de la sociedad, provocando momentos tanto para la creación de lo social como para la subversión de lo consensuado. ${ }^{3}$

Todo lo anterior provocará una ampliación del campo artístico, ya que el arte puede ser un objeto pero también podría ser una acción, puede ser una creación pero también algo encontrado y resignificado, puede estar en los museos y también fuera de ellos, puede ser una reproducción de la realidad pero también una ficción, un escape y una invitación por las más variadas sendas; en tal sentido, las manifestaciones del arte pueden comprender sus formas más clásicas como literatura, pintura, escultura, ópera, teatro y cine, pero también otras más recientes como fotografía, cómic, gastronomía, entre otras representaciones.

Dicho lo anterior, me adscribo a esta segunda postura en la que "(e)l arte es un estado de encuentro". ${ }^{4}$ Propongo entonces un encuentro con la memoria, circunscribiéndome en el espacio de Iberoamérica y temporalmente en las huellas indelebles que han dejado procesos masivos de violación de derechos humanos ocurridos du-

2. Harold Bloom, "Elegía al canon”, en El canon literario, ed. por Enric Sullà (Madrid: Arco/Libros, 1998), 191-218.

3. Nicolas Bourriaud, "La forma relacional", en Estética relacional, 2. a ed. (Buenos Aires: Adriana Hidalgo, 2008), 9-25; Nicolas Bourriaud, "El arte de los años noventa", en Estética relacional, 27-47.

4. Bourriaud, "La forma relacional", ibíd., 17. 
rante la Guerra Civil Española (1936-1939), la dictadura franquista (1936-1975), los golpes de Estado, dictaduras y gobiernos represivos que dominaron a Centroamérica y América del Sur desde comienzos de la década de los cincuenta hasta comienzos de la década de los noventa en el siglo pasado.

Dentro del concepto procesos masivos de violación de derechos humanos entiendo agrupadas distintas tipologías de crímenes internacionales, concretamente la agresión (uso de la fuerza armada de un Estado contra la soberanía, el territorio o independencia política de otro Estado); el genocidio (destrucción total o parcial de un grupo basándose en razones identitarias como nacionalidad, etnia, raza, religión, ideología, etc.); los crimenes de lesa humanidad (distintas prácticas violatorias de derechos cometidas como parte de un ataque, generalizado y/o sistemático, contra una población civil); y los crímenes de guerra (un catálogo concreto de violaciones de derechos cometidas dentro de un conflicto armado internacional o no internacional). ${ }^{5}$

Dicho encuentro con la memoria lo plantearé mediante el cómic o historieta, que puede ser definido como “(e)l arte y (e)l medio masivo de comunicación, caracterizado por presentar ilustraciones e imágenes yuxtapuestas en secuencia, vinculadas temáticamente de forma deliberada, con el objeto de transmitir información y generar una respuesta del lector, para lo cual se basa en sus propias técnicas y convenciones, como especie particular de narrativa gráfica". 6

Antes de seguir es ineludible referirme a la conceptualización de la memoria, la cual se constituye en una categoría compleja y transversal a todos los campos del conocimiento; por ende, sus interpretaciones serán múltiples dependiendo de si el abordaje es realizado desde la medicina, la psicología, la historia, la geografía, la sociología, la antropología, el derecho, etc. Para cumplir el propósito de este ensayo me limitaré a explorar con brevedad el entendimiento de la memoria desde lo etimológico, lo cotidiano, la neurociencia y su dimensión como un derecho humano.

\section{ACERCA DE LA CONCEPTUALIZACIÓN DE LA MEMORIA}

La palabra memoria etimológicamente proviene del latín memorĭa y memoriae, y su significado originario hace referencia a la facultad psíquica de recordar, es decir,

5. Organización de las Naciones Unidas (ONU): Asamblea General, Estatuto de Roma de la Corte Penal Internacional, 17 de julio de 1998.

6. Danilo Caicedo Tapia, "Cómic: una herramienta metodológica para la educación en y para los derechos humanos" (tesina de máster, Universidad Carlos III de Madrid, 2014), 72, 〈https://e-archivo.uc3m.es/ handle/10016/19892>. 
de almacenar en la mente un determinado suceso pasado. De tal manera que el concepto de memoria se encuentra indefectiblemente ligado al recordar, y esa esencia no ha variado hasta nuestros días. En lo actual y cotidiano la palabra memoria designa la idea de guardar registro de lo acontecido por cualquier medio, así también puede significar la expresión oral, escrita o una representación mediante imágenes de lo acontecido. $^{7}$

Desde las posturas y estudios más recientes de la neurociencia se señala que la memoria humana no es una función o facultad neurológica simple, autónoma y concentrada en un lugar, sino que constituye todo un conjunto de procesos neuronales que "son el resultado de una compleja articulación creativa de numerosos sistemas de memoria", ${ }^{8}$ entre los que se encuentran nuestro sentidos, los símbolos y el lenguaje. ${ }^{9}$ Desde la neurociencia se sostiene además que el recordar es una reconstrucción altamente creativa y no una mera reproducción de la realidad; en esta reconstrucción entrarán en juego factores internos y externos al individuo y elementos tanto personales como sociales. ${ }^{10}$

Ahora, desde el derecho se sostiene desde hace poco tiempo la existencia de un derecho humano a la memoria, y, en correspondencia, un deber estatal de guardar memoria o recordar. Para esto, se parte de vincular a la memoria con los derechos a la verdad, la justicia y la reparación que ostentan todas las víctimas de las más graves violaciones de derechos humanos, de conformidad con el Derecho Internacional de los Derechos Humanos.

(S)e entenderá por víctima a toda persona que haya sufrido daños, individual o colectivamente, incluidas lesiones físicas o mentales, sufrimiento emocional, pérdidas económicas o menoscabo sustancial de sus derechos fundamentales, como consecuencia de acciones u omisiones que constituyan una violación manifiesta de las normas internacionales de derechos humanos o una violación grave del derecho internacional humanitario. Cuando corresponda, y en conformidad con el derecho interno, el término "víctima" también comprenderá a la familia inmediata o las personas a cargo de la víctima directa y a las personas que hayan sufrido daños al intervenir para prestar asistencia a víctimas en peligro o para impedir la victimización. ${ }^{11}$

7. Real Academia Española (RAE), Diccionario de la lengua española, 23. ${ }^{a}$ ed., hhttp://lema.rae.es/drae2001/ srv/search?id=8WXeqLsI3DXX255eEiUg).

8. Daniel Feierstein, Memorias y representaciones sobre la elaboración del genocidio (Buenos Aires: Fondo de Cultura Económica, 2012), 24.

9. Ibíd.

10. Ibíd., 23-8.

11. Asamblea General de las Naciones Unidas, Principios y directrices básicos sobre el derecho de las víctimas de violaciones manifiestas de las normas internacionales de derechos humanos y de violaciones 
La triada de derechos a la verdad, justicia y reparación puede ser explicada de la siguiente manera: Verdad implica el derecho de las personas a conocer con la mayor claridad y plenitud la suerte de las víctimas y los hechos relacionados con la violación; aquello implica también la revelación pública de lo acontecido. Justicia es la debida investigación, enjuiciamiento y sanción de los participantes en la violación. Reparación es enmendar de manera adecuada, efectiva y rápida el daño causado, así como la promoción de la justicia por todos los medios necesarios (restitución, indemnización, rehabilitación, satisfacción y garantías de no repetición.). ${ }^{12}$

A partir de lo anterior se puede indicar que el derecho a la memoria se configura como un derecho a conocer, reconocer y recordar: ¿Quiénes fueron las víctimas? ¿Quiénes fueron los perpetradores? ¿En qué contexto y circunstancias ocurrieron los hechos? ¿Cuál fue el contexto general de la violación? Como queda establecido, este derecho no solamente tiene una dimensión individual en relación con las víctimas, sino también con toda la sociedad como interesada, necesitada y afectada en su conjunto. ${ }^{13}$

Correlativamente al derecho a la memoria existe el deber del Estado de recordar, el cual implica solventar estas preguntas y muchas otras, y, en general, tomar todas las medidas necesarias (de acción y abstención) para respetar y garantizar este derecho, convirtiéndose al mismo tiempo en una forma de reparación.

De tal manera que la obligación de recordar no solo implica la recuperación de la memoria, sino también su mantenimiento y, de ser el caso, su reconstrucción. ${ }^{14}$ Con esta última se da paso a una nueva memoria y relato oficial, una colectiva, que no sea impuesta ni artificial. ${ }^{15}$ Parte de las obligaciones del Estado respecto a la memoria también será combatir toda forma de negacionismo o rechazo a la existencia de lo ocurrido, no justificar lo sucedido pretendiendo la legitimidad de los actos, ni minimizar la magnitud de los hechos. ${ }^{16}$

graves del derecho internacional humanitario a interponer recursos y obtener reparaciones, Resolución 60/147 aprobada el 16 de diciembre de 2005, principio V, 〈http://www.ohchr.org/SP/ProfessionalInterest/ Pages/RemedyAndReparation.aspx>.

12. Ibíd., principios VII, VIII, IX, IX.

13. Felipe Gómez Isa, "El derecho de las víctimas a la reparación por violaciones graves y sistemáticas de los derechos humanos", en El derecho a la memoria, ed. por Felipe Gómez Isa (Bilbao: Alberdania, 2006), $37-41$.

14. Ibíd.

15. Este punto es mayormente desarrollado en un trabajo previo de mi autoría titulado Crímenes de lesa humanidad y violaciones de derechos. La actuación de la Comisión de la Verdad Ecuador (Quito: UASB, 2014), 14-7.

16. Emanuela Fronza, "La protección penal de la memoria: sobre el delito de negacionismo", en Memoria y 
Cabe aclarar que aunque jurídicamente el Estado es el obligado a cumplir con este derecho, ${ }^{17}$ los procesos de memoria son mucho más amplios en cuanto a sujetos involucrados y contenido; así, la sociedad en su conjunto juega un rol preponderante en cuanto al recordar, recuperar y reconstruir la memoria de hechos violatorios de derechos humanos, y dentro de las distintas manifestaciones sociales la cultura y el arte son una pieza fundamental en lo que se suele denominar: "cultura de las víctimas" y "cultura de la memoria", ${ }^{18}$ construyendo además una "pedagogía de las víctimas" y una "pedagogía de la memoria". ${ }^{19}$

Ahora bien, ¿cuáles serían las principales funciones de la memoria? Citando a Eva Fontes en "Somos quienes recordamos que somos", autora y artículo ficcionales creados por Miguelanxo Prado en su cómic Ardalén:

Somos lo que recordamos y lo que los demás recuerdan de nosotros. La constatación de nuestra realidad como seres vivos está basada, ciertamente, en el cúmulo de información sensorial que nos llega en el momento presente, pero la consciencia de nuestra identidad en perspectiva, lo que da sentido a nuestros sentimientos, a nuestros temores, a nuestros deseos, lo que nos confiere un atisbo de coherencia a lo largo del tiempo de eso que llamamos vida, nuestra identidad, se sostiene sobre el entramado de la memoria. ${ }^{20}$

Mercedes Prieto Dunwald en "No hay presente", otra de las autoras y artículo ficcional de Miguelanxo Prado, dice: "El tiempo es una obsesión para el ser humano desde siempre. Gracias a que somos inteligentes podemos percibirlo. Y gracias a que tenemos memoria asociada a esa inteligencia, podemos ordenar nuestras experiencias y conocimientos cronológicamente y planificar lo que queremos hacer en el futuro". ${ }^{21}$

Las dos citas precedentes coinciden con lo dicho por el humanista, psiquiatra y neurólogo Carlos Castilla del Pino, quien afirmaba que la memoria, siempre personal, es ese instrumento que las personas utilizamos para interactuar con la realidad, sir-

derecho penal, ed. por Pablo D. Eiroa y Juan M. Otero (Buenos Aires: Fabián J. Di Plácido editor, 2007), 144-6.

17. Una sentencia (especialmente penal) puede tener un gran valor para la memoria individual y colectiva; al respecto ver, por ejemplo: Tatiana Rincón, "La decisión judicial en la construcción de la memoria colectiva", en Memoria y Derecho Penal, 217-35.

18. Gómez Isa, "El derecho de las víctimas a la reparación", 25-41.

19. Gloria Ramírez, "La educación superior en derechos humanos y el papel de la pedagogía de la memoria", en Pedagogía de la memoria. Desafio para la educación en derechos humanos (Santiago de Chile: Heinrich Böll Stiftung Cono Sur, 2010), 33-4.

20. Miguelanxo Prado, Ardalén, 3. ${ }^{a}$ ed. (Barcelona: Norma, 2012), 59.

21. Ibíd., 125. 
viendo tanto de "condición necesaria para el logro de nuestra identidad", 22 como para elaborar "nuestra conciencia del tiempo". ${ }^{23}$

Partiendo de lo anterior, se podría afirmar que las personas somos memoria individual, y colectivamente hablando, nuestra interacción y relaciones personales y sociales se basan en nuestra evocación del pasado, que a la vez conduce a la interpretación del presente y la proyección hacia el futuro. Nuestros recuerdos como conocimiento (con)forman realidades, crean sentido de pertenencia y de exclusión, establecen o invierten categorías (víctimas y victimarios), justifican o condenan actos (actos heroicos o violaciones), y en últimas causas, dan sentido a la historia. Al mismo tiempo, el olvido, la amnesia y la amnistía respecto a las violaciones de derechos humanos significarán injusticia e impunidad. ${ }^{24}$

Todo lo anterior confluye además en la conformación de un campo de naturaleza interdisciplinar al que puede denominarse como estudios o trabajos de la memoria. En este espacio del conocimiento se suman distintas disciplinas: además de la neurociencia y el derecho antes nombradas, se pueden mencionar "el psicoanálisis, la sociología, la ciencia política, la antropología y la historia", ${ }^{25}$ y desde mi posición particular también añadiría al arte.

Al respecto, es de suma importancia mencionar, como bien lo señala Elizabeth Jelin, que este tipo de estudios en América Latina, y en especial en el Cono Sur, tienen una identidad o señas particulares mediante la vinculación de la memoria con los conceptos de democracia y derechos humanos, esto producto de la cruenta historia de la región en las últimas décadas del siglo XX y de las luchas de los movimientos sociales por la reivindicación de la memoria de lo ocurrido, el establecimiento de responsabilidades estatales y la exigencia de no repetición. ${ }^{26}$ Por tanto, desde una perspectiva contemporánea no se deben perder de vista las distintas aristas de la memoria, con especial énfasis en las relaciones entre memoria, derechos humanos, democracia y arte.

22. Carlos Castilla del Pino, "La forma moral de la memoria. a manera de prólogo", en El derecho a la memoria, ed. por Felipe Gómez Isa (Bilbao: Alberdania, 2006), 19.

23. Ibíd., 18.

24. La sanción más severa y cruenta en la Antigua Roma se denominaba damnatio memoriae, que significaba una condena pública a la memoria contra el enemigo del Estado, implicaba su olvido generalizado y eliminación de todo registro de su existencia. Sobre el tema ver, por ejemplo: Carlos Crespo Pérez, La condenación al olvido (damnatio memoriae) (Madrid: Signifer Libros, 2014).

25. Elizabeth Jelin, Los derechos humanos y la memoria de la violencia política y la represión: la construcción de un campo nuevo en las ciencias sociales (Buenos Aires: Instituto de Desarrollo Económico y Social, 2003), 20-3.

26. Ibíd., 13-20. 


\section{UNA MIRADA A LA MEMORIA DE PROCESOS MASIVOS DE VIOLACIÓN DE DERECHOS MEDIANTE EL CÓMIC}

Establecida la conceptualización y relevancia social del arte y mutatis mutandis del cómic como representación artística, así como también determinado el contenido e importantes funciones de la memoria, es hora de entrar de lleno con la exploración del cómic.

Considero pertinente un par de aclaraciones: primera, acudiré a una selección no exhaustiva de obras de cómic de Iberoamérica sobre las temáticas mencionadas, basaré mi criterio en su disponibilidad, pertinencia, novedad e interés; buscaré destacar además cómics que sirvan como alternativas de resistencia ante la historia oficial impuesta. Segunda, omitiré al comic strip, también llamado tiras de periódico o caricatura, puesto que la riqueza de dicha especie de cómic merece un estudio particular. En tercer lugar, buscaré facilitar la recordación social de los actos de agresión, genocidios, los crímenes de lesa humanidad y los crímenes de guerra, es decir, de los desaparecidos forzadamente, los ejecutados extrajudicialmente, los niños y niñas sustraídos de sus familias, los torturados, los perseguidos, los privados de su libertad de forma arbitraria, los exiliados, los refugiados y, en general, de todas las víctimas de graves violaciones a los derechos humanos. ${ }^{27}$

\section{Cómic, MEMORIA Y VIOLACIONES DE DERECHOS EN LATINOAMÉRICA}

Comienzo por la Argentina con la mencionada obra El Eternauta, concretamente su segunda parte. Con maestría Oesterheld y Solano López continúan con su relato de un futuro apocalíptico, situado en Buenos Aires, ciudad que al igual que el mundo entero han quedado destruidos y reducidos a su forma más primitiva; aun así los seres humanos siguen siendo humanos, los lazos familiares, relaciones de amistad y vínculos sociales tienen enorme importancia, también existe la necesidad de luchar contra la opresión del invasor, que aunque pareciere invencible puede y debe ser vencido para vivir de nuevo como seres libres. Todo esto es contado por el propio Oesterheld, quien funge como narrador y protagonista. (Viñeta 2)

27. Un buen análisis y resumen sobre lo descrito puede ser encontrado en Daniel Feierstein, comp., Terrorismo de Estado y genocidio en América (Buenos Aires: Prometeo, 2009). Así también, en Rafael Escudero Alday, Memoria histórica y democracia en España, la brecha de la transición (México D. F.: Fontamara, 2016). 
Viñeta 2. EI Eternauta II
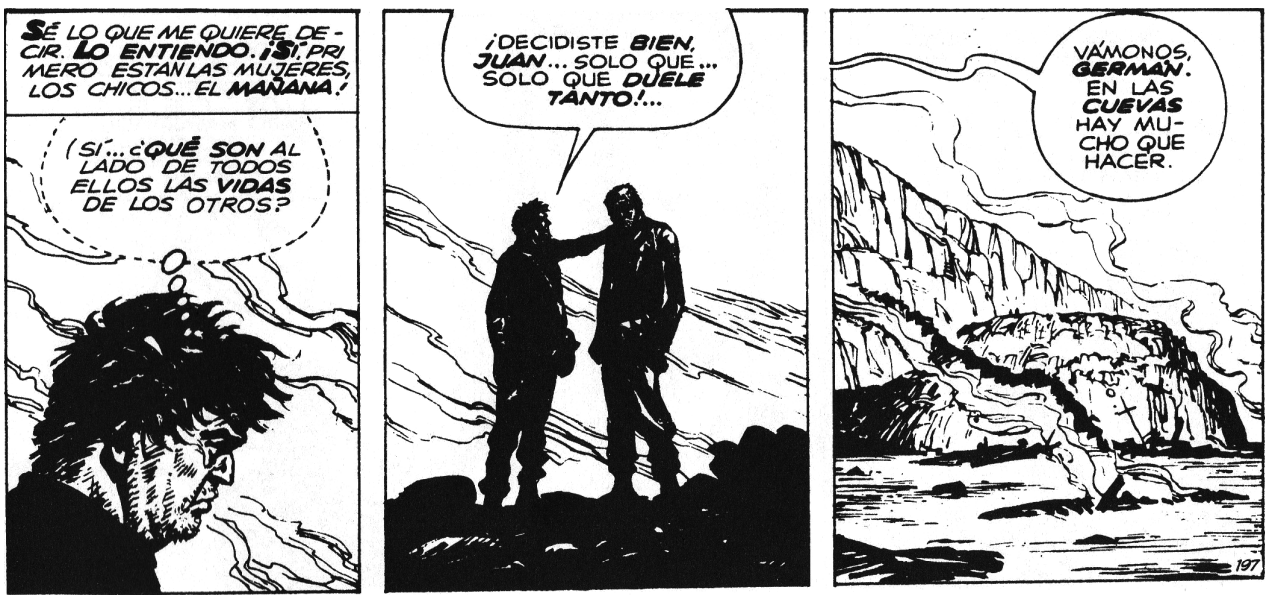

Fuente: Oesterheld y Solano López, El Eternauta. Segunda parte, 207.

Los paralelismos de El Eternauta con lo que ocurría en ese momento en Argentina son en ocasiones sutiles y en otras mucho más evidentes. La dictadura militar pomposamente se autodenominó como Proceso de Reorganización Nacional. Bajo su represión planificada 30.000 personas desaparecieron, sumadas a las miles de otras víctimas de otro tipo de graves violaciones y crímenes de lesa humanidad. Fueron particularmente repudiables las ejecuciones masivas, los llamados vuelos de la muerte, los centros clandestinos de detención, como la infame Escuela de Mecánica de la Armada y el secuestro y robo de identidad de centenares de niños y niñas. ${ }^{28}$ También al recordar la Argentina de la época viene a la mente la lucha de las organizaciones de derechos humanos como las Abuelas de Plaza de Mayo y de las Madres de Plaza de Mayo.

Ahora pasaré a mencionar dos obras sobre las graves violaciones de derechos humanos y crímenes de lesa humanidad ocurridos en Perú. Por una parte, el cómic $R u$ pay (calor, encender, arder en quechua) abarca el período de violencia política entre 1980-1984, y, por otra parte, el cómic Barbarie narra casos ocurridos entre 1985$1990 .{ }^{29}$ (Viñetas 3 y 4)

28. Comisión Nacional sobre la Desaparición de Personas (CONADEP), Nunca Más. Edición del 30 aniversario del Golpe de Estado (Informe Sabato) (Buenos Aires, Eudeba: 2011), 7-9.

29. Para un análisis más completo pude citar además el cómic: Los años del terror. 50 preguntas sobre el conflicto armado en Perú, 1980-2000, también de autoría de Jesús Cossío. 
Viñeta 3. Rupay

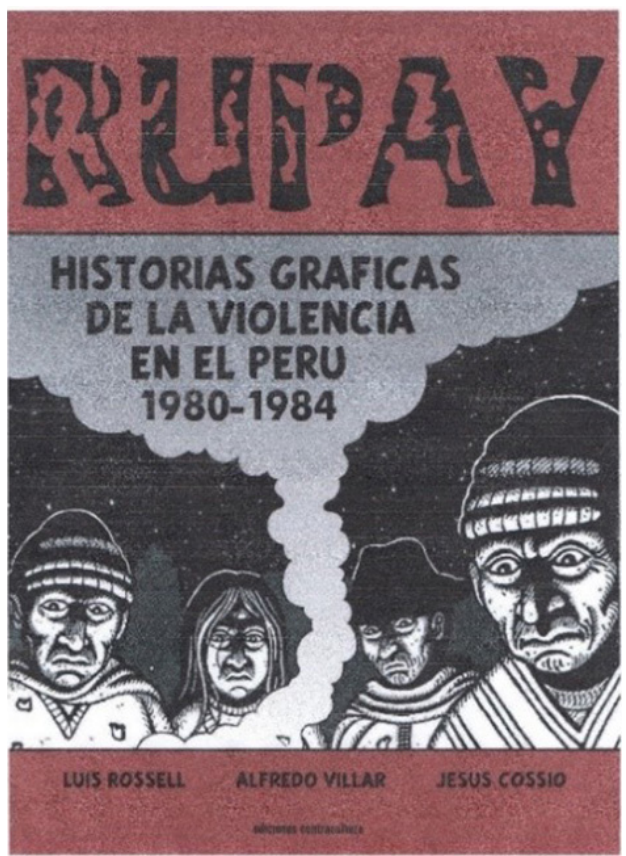

Fuente: Luis Rossell, Alfredo Villar y Jesús Cossío, Rupay (Lima: Contracultura, 2008), portada http:// lum.cultura.pe/cdi/registrobibliografico/rupayhistorias-gr\% $\% 3 \% \mathrm{~A} 1$ ficas-de-la-violencia-en-elper\%C3\%BA-1980-1984〉.
Viñeta 4. Barbarie

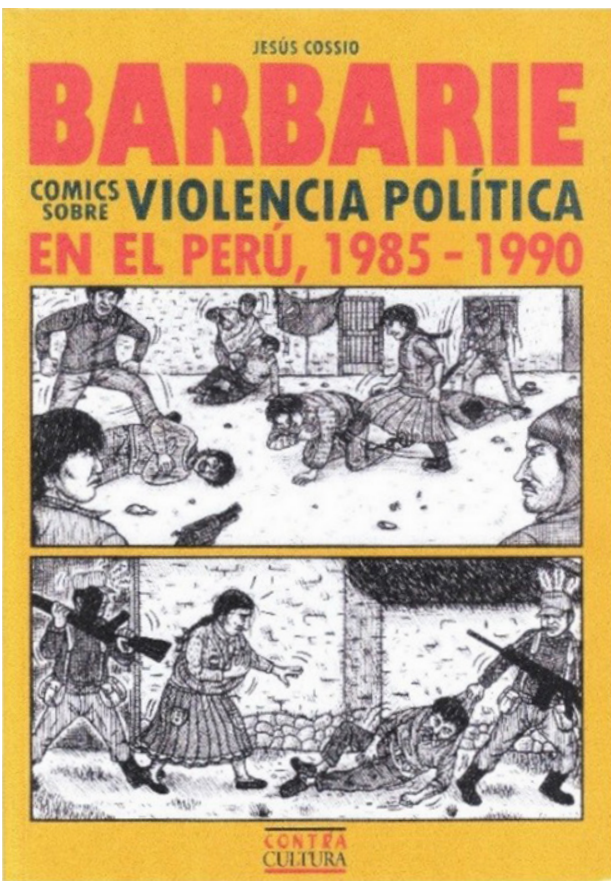

Fuente: Jesús Cossío, Barbarie (Lima: Contracultura, 2010), portada 〈http://lum.cultura.pe/cdi/registrobiblio grafico/barbarie-comics-sobre-violencia-pol\% $\% 3 \%$ ADtica-en-el-per\%C3\%BA-1985-1990 .

Las dos obras altamente documentadas se basan en el Informe de la Comisión de la Verdad y Reconciliación del Perú, en los informes de diversas organizaciones de derechos humanos, testimonios de víctimas e información de prensa; dichos cómics retratan episodios terribles del conflicto entre el Estado peruano, comités de autodefensa y organizaciones subversivas como el Partido Comunista del Perú Sendero Luminoso y el Movimiento Revolucionario Túpac Amaru. ${ }^{30}$

Las cifras oficiales del conflicto fratricida son inciertas, pues con el pasar de los años tienden a elevarse con cada nuevo descubrimiento, dan cuenta de al menos 69.280 víctimas fatales, y de esa cifra además, como lo señaló la Comisión de la

30. Comisión de la Verdad y Reconciliación del Perú, Hatun Willakuy (gran historia o relato) Versión abreviada del Informe Final de la Comisión de la Verdad y Reconciliación (Lima: CVR, 2008 [2004]), 435-45. 
Verdad, su inmensa mayoría fueron personas campesinas, indígenas, con instrucción educativa básica y de escasos recursos económicos. ${ }^{31}$ (Viñeta 5)

\section{Viñeta 5. Rupay (Masacres)}
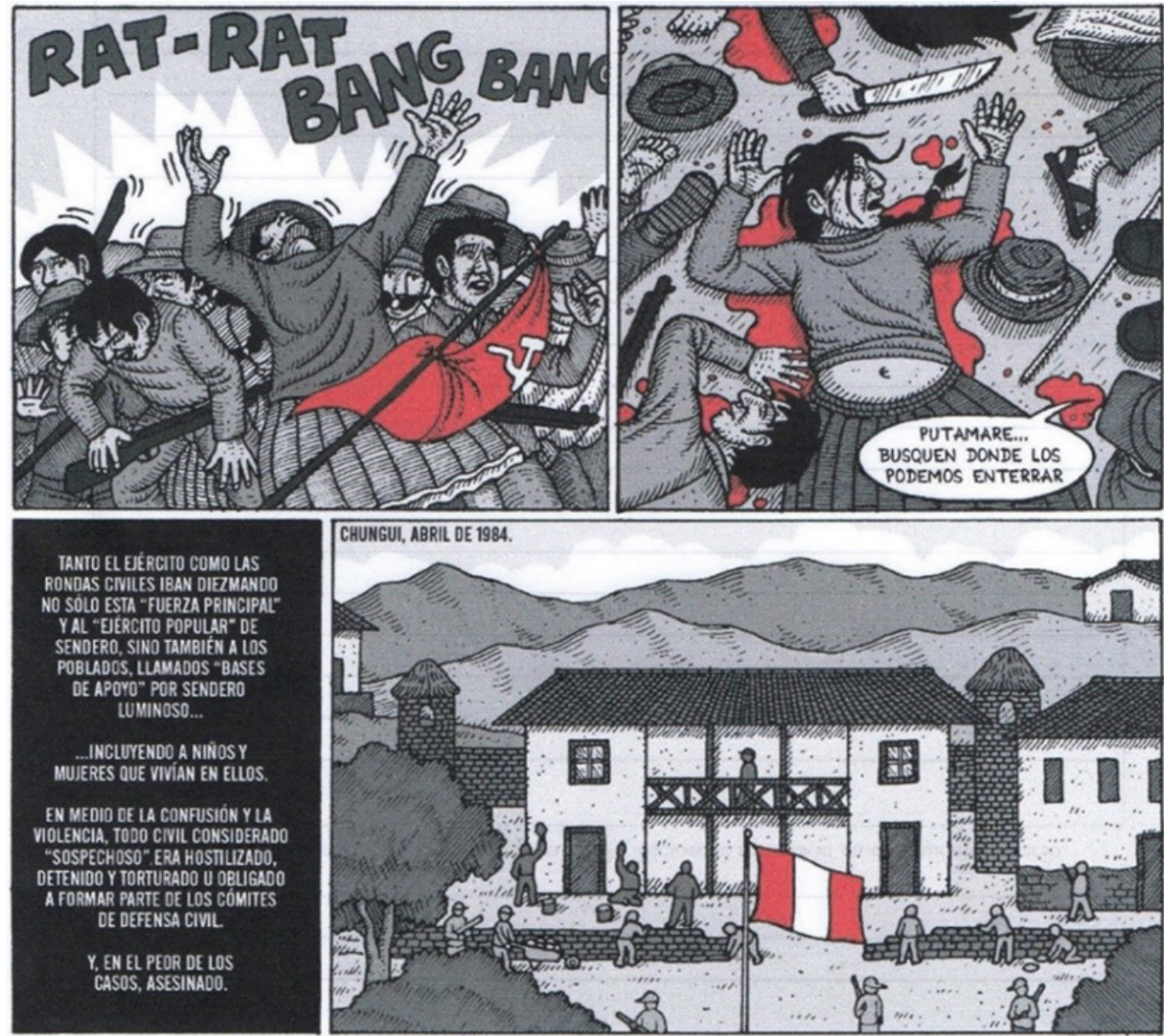

Fuente: Rossell, Villar y Cossío, Rupay, 51.

Chile es otro de los numerosos ejemplos de países de América del Sur en que se cometieron graves violaciones de derechos humanos y crímenes de lesa humanidad en el marco de un proyecto represivo continental. El golpe de Estado del 11 de

31. Ibíd., 433-5. 
septiembre de 1973, encabezado por Augusto Pinochet con el apoyo de los Estados Unidos de América y una gran parte del sector empresarial del país, significaría el comienzo de las políticas generalizadas de represión que se extenderían hasta comienzos de 1990.

Luego de la larga dictadura, varios organismos de investigación fueron creados para verificar el número de víctimas de ese período. La cifra oficial establece más de 40.000 víctimas de distintas violaciones, aunque dicho número ha sido frecuentemente puesto en tela de juicio por considerarlo inferior a la magnitud de lo ocurrido. ${ }^{32}$

El cómic Los años de Allende parte de una historia ficticia protagonizada por un periodista extranjero, quien es el hilo conductor para narrar los principales hechos de la vida y el gobierno de Salvador Allende desde 1970 hasta 1973. La obra, basada en documentación y en el asesoramiento de periodistas, historiadores y consultores, es una buena manera de acercarse al Chile de la época, al pensamiento político de Allende, a la posición de sus contradictores y al panorama político y social del momento, que finaliza con la muerte del presidente chileno, el golpe de Estado y el comienzo de la dictadura. (Viñeta 6)

Respecto a la experiencia chilena, también es relevante mencionar la obra ; Maldito Allende!, la cual se caracteriza por presentar, a través de distintos estilos artísticos, determinados momentos de la vida de Salvador Allende y Augusto Pinochet, y mediante una tercera historia actual se nos muestra en toda su extensión el siempre presente conflicto ideológico, político y social entre los simpatizantes de Allende y Pinochet. (Viñeta 7)

Acerca de Colombia, apenas hace un par de años el cómic se comienza a vincular con su historia. Muestra de ello es el cómic Los Once, el cual se aproxima a un hecho traumático y poco esclarecido en la historia colombiana: el secuestro de personas y la toma del Palacio de Justicia el 6 de noviembre de 1985 por el Movimiento 19 de abril, más conocido como M19, y la posterior intervención del ejército colombiano. Producto de lo anterior cerca de un centenar de personas murieron (se presume que varias ejecutadas) y una decena de personas se encuentran todavía desaparecidas (se presume que varias de forma forzada). ${ }^{33}$

32. Ver las conclusiones de la Comisión Nacional de Verdad y Reconciliación, Informe de la Comisión Nacional de Verdad y Reconciliación (Informe Rettig) (Santiago de Chile: Corporación Nacional de Reparación y Reconciliación, 2007 [1991]). Comisión Nacional sobre Prisión Política y Tortura, Informe de la Comisión Nacional sobre Prisión Política y Tortura (Informe Valech) (Santiago de Chile: Corporación Nacional de Reparación y Reconciliación, 2007 [2003]) Y el Informe de la Comisión Presidencial Asesora para la Calificación de Detenidos Desaparecidos, Ejecutados Políticos y Víctimas de Prisión Política y Tortura, 〈http://pdh.minjusticia.gob.cl/wp-content/uploads/2015/12/informecomisionfase2-1.pdf〉, 51.

33. Ver Corte Interamericana de Derechos Humanos, Caso Rodríguez Vera y Otros (Desaparecidos del Pala- 
Viñeta 6. Los años de Allende
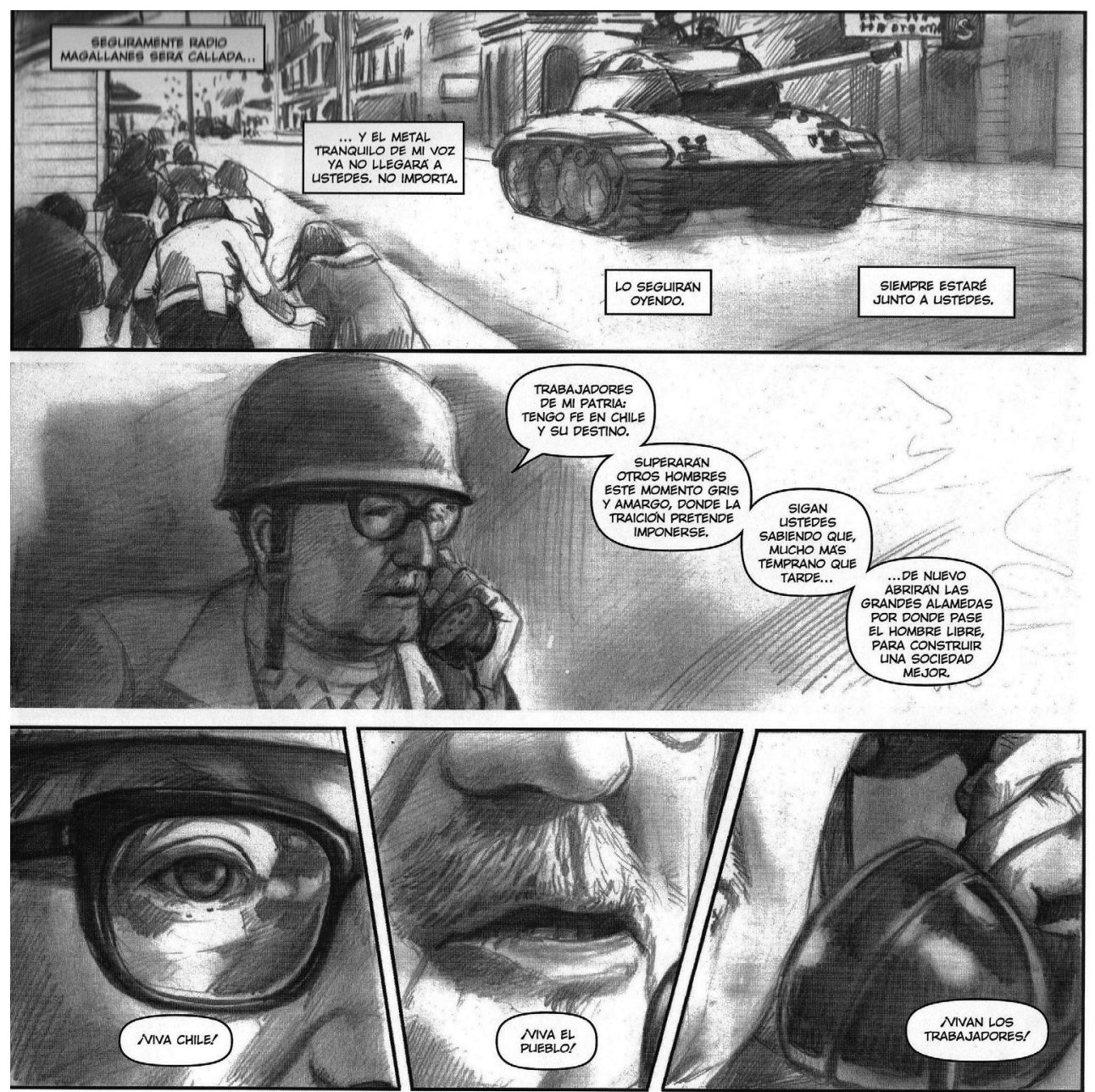

Fuente: Carlos Reyes y Rodrigo Elgueta, Los años de Allende (Santiago de Chile: Hueders, 2015), 114.

cio de Justicia) vs. Colombia, Sentencia de 14 de noviembre de 2014 (Excepciones Preliminares, Fondo, Reparaciones y Costas). 


\section{Viñeta 7. ¡Maldito Allende!}



NO SÉ QUÉ CONTESTARLE. NO PUEDO HABLARLE DELA ADORACIÓN DE MI PADRE HAGIA PINOCHET.

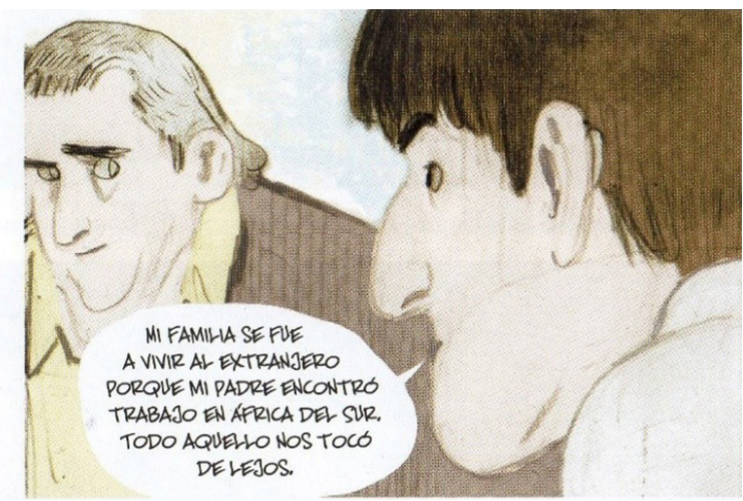

Fuente: Jorge González y Olivier Bras, ;Maldito Allende! (Barcelona: ECC, 2017 [2015]), 43.

A diferencia de otras obras, Los Once no pretende ser una recopilación histórica de lo ocurrido, más bien mediante una historia sencilla protagonizada por ratones y otros animales, es un acercamiento intimista a lo ocurrido, una aproximación a ese día desde los ojos de los habitantes de la Bogotá de aquella época. Cabe aclarar que este cómic abarca tan solo un hecho puntual del complejo y prolongado conflicto colombiano que ha involucrado al ejército colombiano, fuerzas paramilitares, fuerzas subversivas y delincuencia organizada por más de seis décadas. (Viñeta 8)

Centroamérica no fue ajena a los procesos de violación masiva de derechos humanos: Guatemala, Honduras, Nicaragua, República Dominicana, Haití y El Salvador son tan solo algunos de los países que sufrieron la aplicación de la doctrina de la seguridad nacional. ${ }^{34}$

En el cómic La Chelita encontramos un repaso de la historia de El Salvador, un testimonio de su conflicto armado interno y sus múltiples secuelas, a través de la experiencia de Charo Borreguero, una de las autoras de la obra, cooperante en el país y trabajadora de una de las organizaciones de derechos humanos encargadas de recoger testimonios para la Comisión de la Verdad de dicho país. Como en todos los casos, las cifras no son del todo de fiar, pero se estima que entre 1980 y 1992 existieron más de 75.000 víctimas fatales, la mayoría de las violaciones fueron cometidas por el propio Estado y un número reducido por grupos guerrilleros. ${ }^{35}$ (Viñeta 9)

34. Daniel Feierstein, "Guerra, genocidio, violencia política y sistema concentracionario en América Latina", en Terrorismo de Estado y genocidio en América, ed. por Daniel Feierstein (Buenos Aires: Prometeo, 2009), 11-9.

35. Comisión de la Verdad para El Salvador, Informe Comisión de la Verdad para El Salvador. De la Locura 


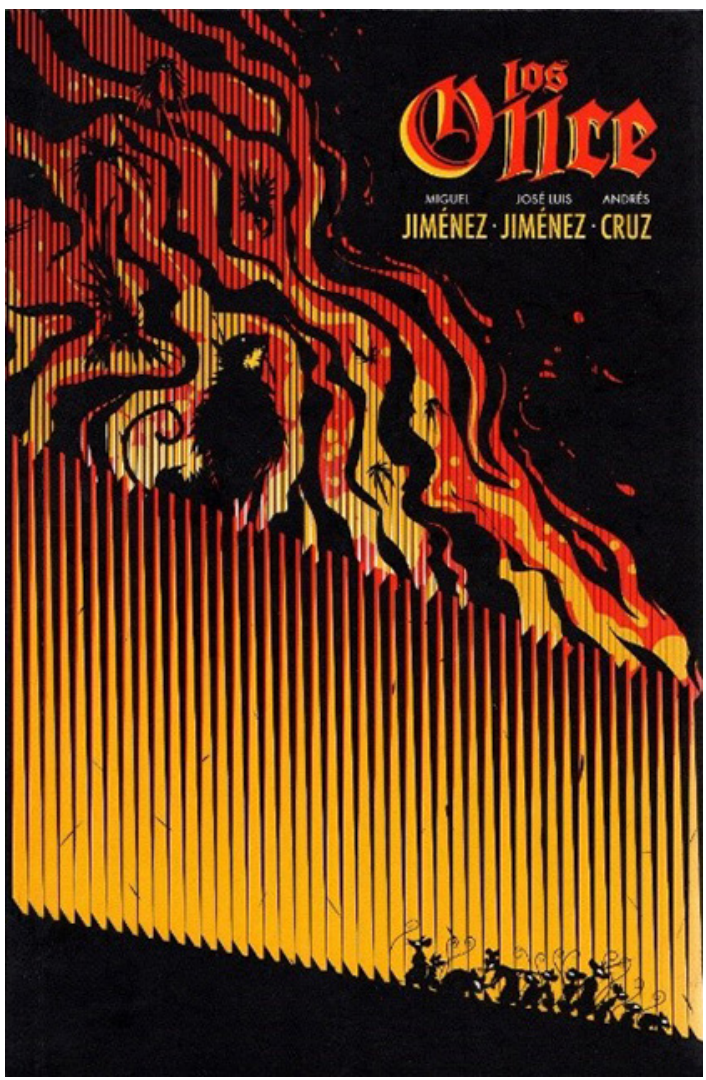

Fuente: Miguel Jiménez, José Luis Jiménez y Andrés Cruz, Los Once (Bogotá: Laguna, 2014).

Como corolario de esta sección puedo señalar que el cómic latinoamericano que explora los procesos de violación de derechos humanos en las últimas décadas del siglo XX es de muy reciente elaboración, salvando el caso argentino. Se trata de obras variopintas tanto en forma como en contenidos. Sin embargo, como esencia compartida se mantiene la manifestación de un relato alterno al oficial -estatal-; el relato de los acontecimientos en un contexto global que supera y condiciona los hechos vividos en Latinoamérica, la utilización de un discurso que explora en todos los niveles el impacto del conflicto, con especial atención en el entorno familiar; el rescate a la figura de

a la Esperanza: La guerra de los Doce Años en El Salvador, 1992-1993, 〈http://www.derechoshumanos. net/lesahumanidad/informes/elsalvador/informe-de-la-locura-a-la-esperanza.htm〉. 
Viñeta 9. La Chelita. EI Salvador 1992

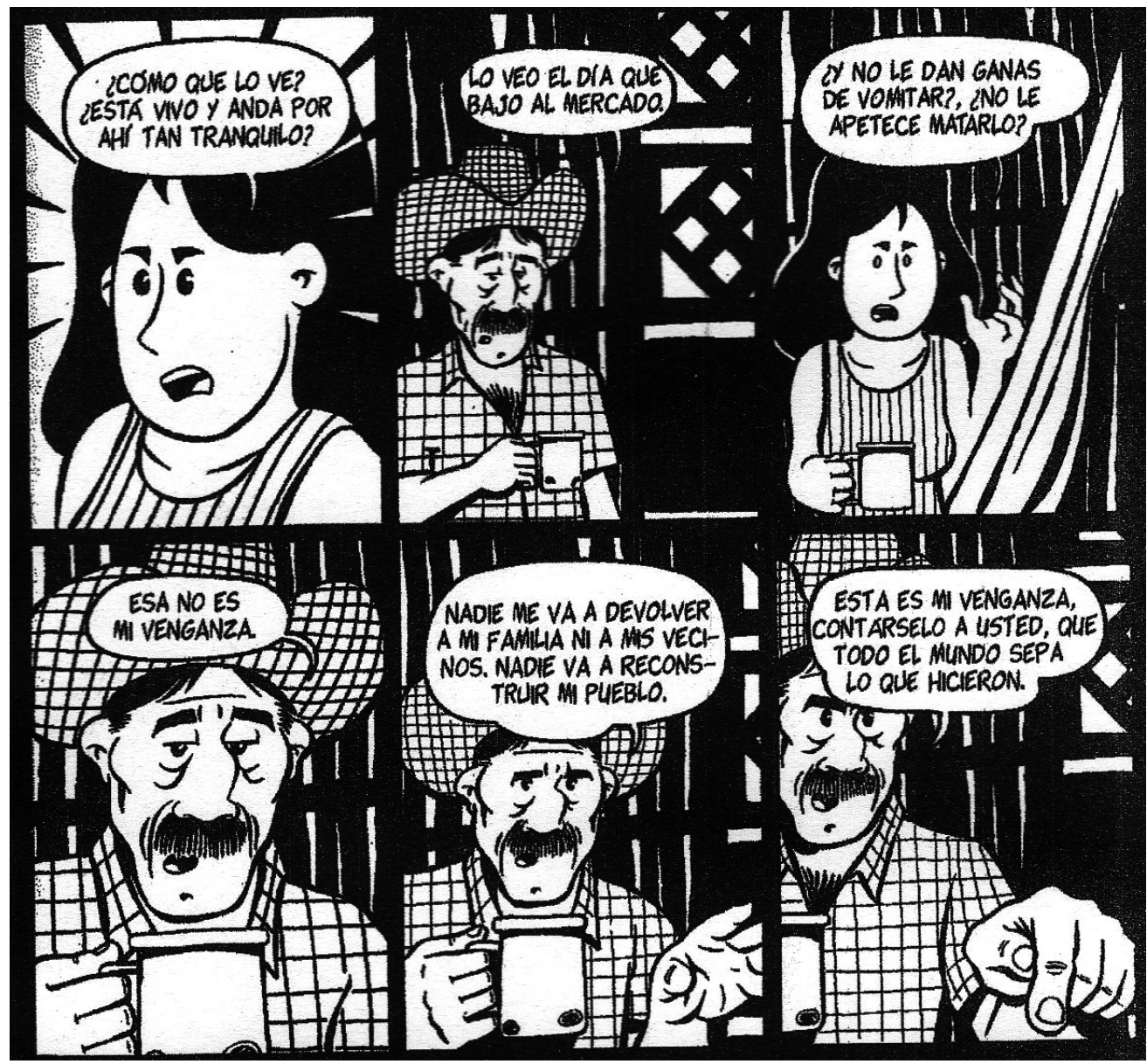

Fuente: Ruma Barbero y Charo Borreguero, La Chelita. El Salvador 1992 (Palma de Mallorca: Dolmen, 2013), 85 .

la otredad vencida -las víctimas-; la presentación sin filtros de las acciones y actores de quienes son considerados victimarios; y la dificultad para superar los episodios traumáticos en un contexto de impunidad. 


\section{CÓMIC, MEMORIA Y VIOLACIONES DE DERECHOS EN ESPAÑa}

Lo ocurrido durante la Guerra Civil Española y la posterior dictadura franquista son un claro ejemplo de violaciones masivas de derechos humanos, seguidas de ausencia de verdad, justicia y reparación. La Guerra Civil Española fue un conflicto armado interno de enormes proporciones entre el bando republicano y el bando nacionalista; como resultado de dicho conflicto se implanta una dictadura y un proceso represivo que se proyectó en todos los espacios sociales y que se prolongó en el tiempo con distintas intensidades, incluso perpetuándose hasta nuestros días bajo la forma del silencio y la impunidad, presentados como una transición modélica a la democracia.

A diferencia de Latinoamérica, en el caso español incluso dar una estadística aproximada de las victimas resulta más complejo. Esto en razón de que no existe estimación oficial, ${ }^{36}$ los estudios del tema no cuentan con el apoyo estatal, las investigaciones son parciales e incompletas y en algunos casos también son investigaciones ideológicamente parcializadas. ${ }^{37} \mathrm{Sin}$ embargo, las víctimas fatales se suelen cifrar por encima de las 200.000 personas y los desaparecidos forzadamente en alrededor de $150.000,{ }^{38}$ esto, como lo señala Rafael Escudero Alday, sumado a variadas y numerosas violaciones realizadas en un marco generalizado y sistemático de exterminio de opositores y represión de la población. ${ }^{39}$

La pasividad del Estado español por dotar de claridad a lo ocurrido ha sido observada reiteradamente por la comunidad internacional; por ejemplo, en 2006 la Comisión Permanente de la Asamblea Parlamentaria del Consejo de Europa expidió una

36. ElDiario.es, "Un informe del Consejo de Europa abronca a España por abandonar a las víctimas del franquismo", 〈https://www.eldiario.es/sociedad/Europa-Espana-abandono-victimas-desaparicion_0_495901430.html〉.

37. Una explicación clarificadora respecto a la enorme complejidad y dificultad para establecer la real magnitud y el número de víctimas totales del conflicto puede ser encontrada en Paul Preston y José Pablo García, $L a$ Guerra Civil Española (Barcelona: Debate, 2016), 228-39. (Hago notar que he citado la versión en cómic).

38. Ver, por ejemplo, Miguel Ángel Arias Rodríguez y Salvador López Arnal, "Entrevista a Miguel Ángel Rodríguez Arias: Desaparecidos del franquismo, trato inhumano a las familias e impunidad", Papeles de relaciones ecosociales y cambio global, n. ${ }^{\circ} 108$ (2009): 133-43; también la nota de prensa Elmundo.es, "Garzón recibe más de 140.000 nombres de desaparecidos en la Guerra Civil y la dictadura", 〈http://www.elmundo. es/elmundo/2008/09/22/espana/1222093274.html;; y Radio, "Recuperando Memoria. Desmontando las cifras de la Fundación Francisco Franco sobre la represión franquista”. Audio y texto, 〈https://radiorecuperandomemoria.com/2016/11/22/desmontando-las-cifras-de-la-fundacion-francisco-franco-sobre-la-represionfranquista/s.

39. Rafael Escudero Alday, "Memoria histórica e imperio de la ley: el poder judicial ante el derecho a la reparación de las víctimas del franquismo", Derechos y Libertades. Revista de Filosofía del Derecho y Derechos Humanos, n. ${ }^{\circ}$ 38, Época II (2018): 78. 
resolución en la cual se condenan "las graves violaciones a los derechos humanos cometidas en España por el régimen franquista de 1939-1975", instando a la acción efectiva del Estado español y a la toma de medidas para brindar justicia y rescatar la memoria de las víctimas. ${ }^{40}$

Así también, el Grupo de Trabajo sobre las desapariciones forzadas o involuntarias de las Naciones Unidas, luego de una visita al país brindó numerosas recomendaciones, las cuales en su criterio no han tenido mayor implementación. Se cita por ejemplo, la creación de una comisión de la verdad, el establecimiento de mecanismos para la búsqueda de desaparecidos y la exhumación de restos, el retiro de monumentos y símbolos franquistas, y la realización de modificaciones legislativas para emprender procesos de justicia. ${ }^{41}$

Adentrándonos en el mundo del cómic, la Guerra Civil y la dictadura franquista han sido exploradas en numerosas obras, ${ }^{42}$ incluso como señala María Acaso, en los primeros años del conflicto armado interno se desarrolló cómic de bando y bando. ${ }^{43}$ Pero el cómic de denuncia de las masivas violaciones de derechos humanos se puede encontrar recién con el proceso de transición y retorno a la democracia. Diversas revistas dedicaban números enteros o amplias secciones a hablar de lo que les había estado prohibido durante décadas. Esa época oscura en la que se vieron limitados por códigos censores conservadores y que condujeron a desarrollar un cómic humorístico, costumbrista, simplista e inofensivo. ${ }^{44}$

Es sumamente interesante mencionar también el estudio de Nestor Bórquez, en el que el autor muestra la existencia de ciertos patrones comunes entre la gran mayoría de la producción de narrativa gráfica que explora los sucesos de la Guerra Civil y el franquismo: 1. la vinculación entre relato de ficción y exploración documental; 2. la naturaleza autobiográfica, literaria testimonial y de relato personal; 3 . la relación entre

40. Asamblea Parlamentaria del Consejo de Europa, Need for International Condemnation of the Franco Regime, Recomendación 1736 de 17 de marzo de 2006. Disponible en inglés: «https://search.coe.int/cm/ Pages/result_details.aspx?ObjectID $=09000016805 \mathrm{c} 169 \mathrm{~d}$.

41. Grupo de Trabajo sobre las Desapariciones Forzadas o Involuntarias de las Naciones Unidas, Informe de Seguimiento de Recomendaciones Realizadas a España, Resolución A/HRC/36/39/Add.3, de 7 de septiembre de 2017. Desde la página 120 en adelante, 〈https://documents-dds-ny.un.org/doc/UNDOC/GEN/ G17/260/51/PDF/G1726051.pdf?OpenElement).

42. Ver, por ejemplo, un listado ejemplificativo: nota de prensa ElPeriodico.com, "La Guerra Civil en 10 cómics", 〈https://www.elperiodico.com/es/ocio-y-cultura/20160718/guerra-civil-diez-comic-5274920;; y en especial: Michel Matly, "El cómic español y la Guerra Civil: transición y primera década de democracia

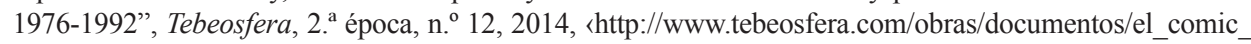
espanol_y_la_guerra_civil_transicion_y_primera_decada_de_democracia_-_1976-1992.html〉.

43. Ana Merino, El cómic hispánico (Madrid: Catedra, 2003), 101-4.

44. Ibíd., 97-145. 
distintas generaciones afectadas directa e indirectamente por el hecho traumático; 4. el rescate del relato del olvidado, del silenciado y del vencido; 5 . la presencia de temáticas comunes en torno al conflicto y el posconflicto, con especial atención en actos de vulneración de derechos humanos y situaciones límite. ${ }^{45}$ (Viñetas 10 y 11)

Viñeta 10. 17 días de julio

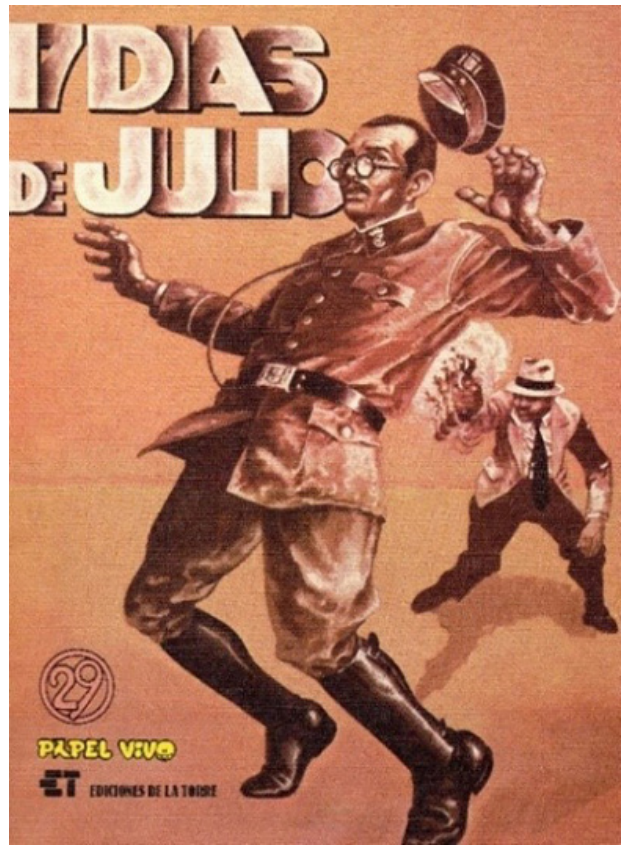

Fuente: Luis Murillo y Justo Jimeno, 17 dias de julio (Madrid: De la Torre, 1982).
Viñeta 11. Dossiers

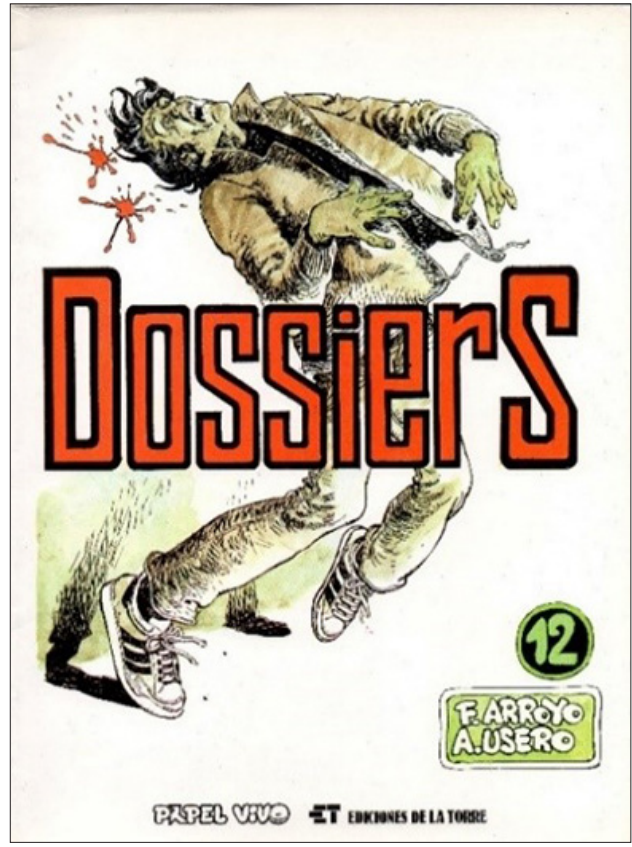

Fuente: Francisco M. Arroyo y Adolfo Usero, Dossiers (Madrid: De la Torre, 1980).

Aquí me centraré en destacar algunos cómics que hacen referencia a la memoria de lo ocurrido en España desde distintas perspectivas. Comenzaré por centrarme en varias obras de Carlos Giménez, algunas de ellas con carácter cercano a lo autobiográfico, otras basadas en la experiencia de terceros y contando con determinados elementos de ficción. Destacaré de su amplio catálogo repartido en numerosas revistas,

45. Nestor Bórquez, "La historieta de la memoria: la Guerra Civil y el franquismo en viñetas", Diablotexto Digital, n. ${ }^{\circ} 1$ (2016): 29-41. 
a los libros compilatorios Paracuellos y Barrio, que parten de la experiencia personal del autor. (Viñeta 12)

Viñeta 12. Paracuellos

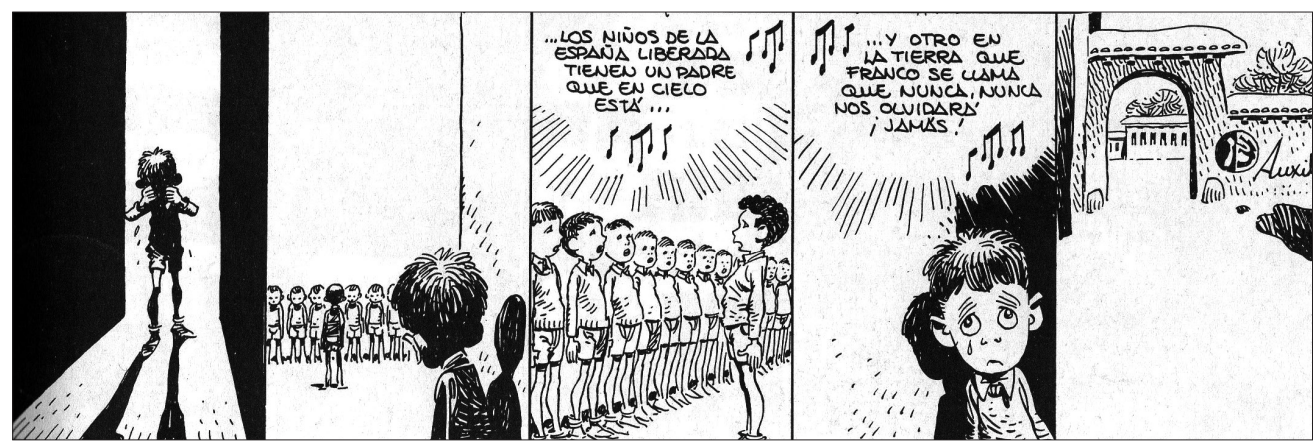

Fuente: Carlos Giménez, Paracuellos, 7.a ed. (Barcelona: Debols!1lo, 2012 [1977]), 71.

En estas obras Carlos Giménez nos traslada vívidamente a la vida del niño y del adolescente durante la España franquista. Con gran habilidad, en Paracuellos nos pone en los zapatos del niño que se encuentra en un "auxilio social", un reclusorio franquista que se maneja bajo la lógica de una auténtica prisión combinada con un campo de reeducación para niños; mientras que en Barrio nos muestra las vivencias de crecer en un barrio popular de Madrid en un entorno de posguerra: la vida sigue y se desenvuelve con la normalidad permitida por un régimen totalitario, ultracatólico, conservador y corrupto, y en ausencia del bando republicano, el cual ha sido desterrado física e ideológicamente. (Viñeta 13)

El arte de volar, obra cumbre del cómic español, presenta con seriedad, madurez y fundamentación otra óptica de lo ocurrido. Kim como dibujante y Antonio Altarriba como guionista, nos cuentan la vida del padre de este último, Antonio Altarriba Lope, y a través de ella la República, el franquismo, la transición democrática y la España actual. Todas pasan frente a nuestros ojos al tiempo que acompañamos a Antonio (padre) desde su niñez hasta su vejez, cerrando dicha travesía con su suicidio. Un retrato descarnado de una generación volcada al cambio que no pudo ser, al abandono de sus valores, ideales y toda esperanza. ${ }^{46}$ (Viñeta 14)

46. Aunque son obras independientes, El arte de volar se complementa con el cómic El ala rota, que cuenta la historia de España desde la perspectiva de la madre de Antonio Altarriba. 
Viñeta 13. Barrio

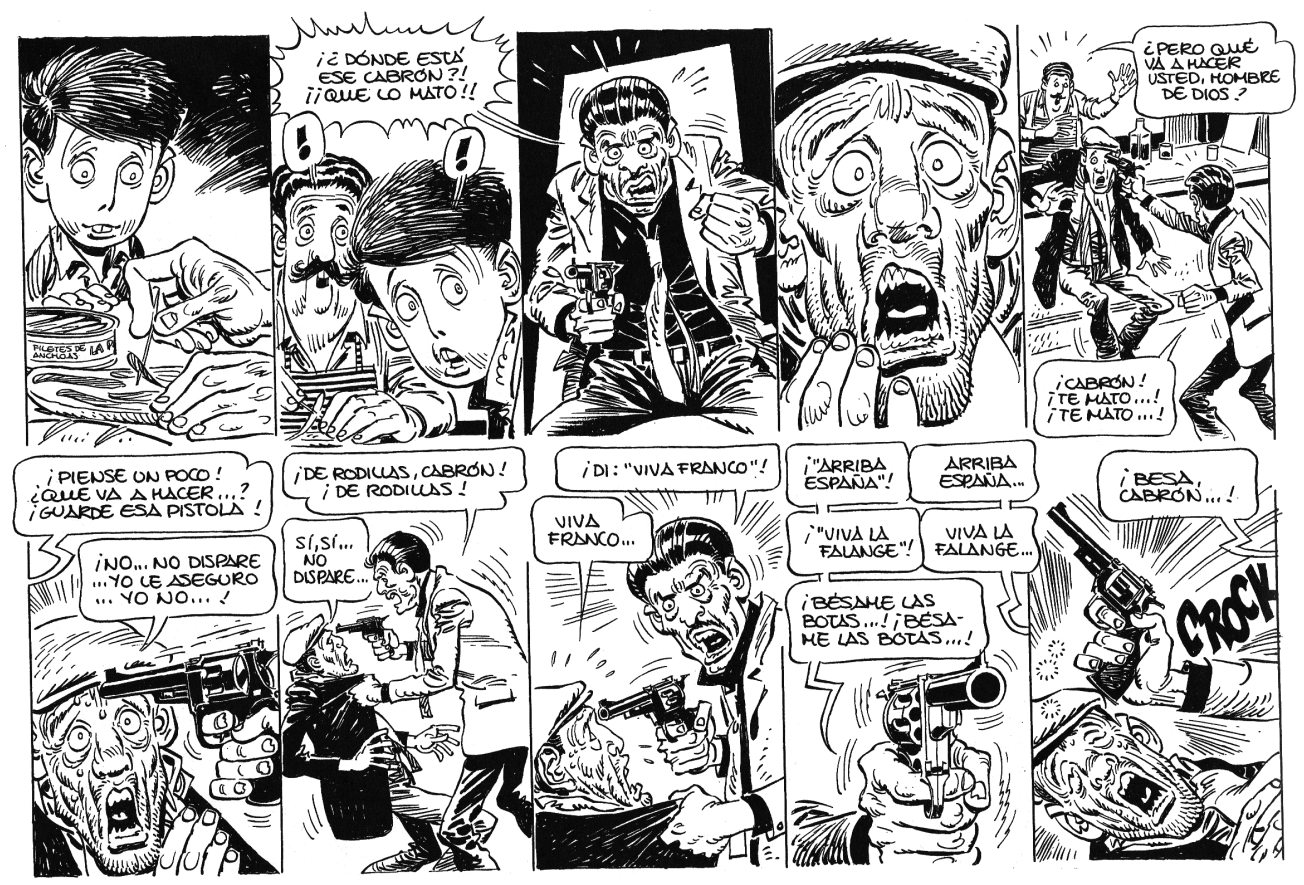

Fuente: Carlos Giménez, Barrio (Barcelona: Debols!1lo, 2011 [1978]), 38.

Paco Roca en Los surcos del azar, obra que denota gran estudio e investigación en su creación, explora también la Guerra Civil y la dictadura franquista, pero además contextualiza a España en el concierto internacional durante la Segunda Guerra Mundial. Esta obra en la que la línea entre ficción y realidad es prácticamente imperceptible, nos cuenta a través de la relación de Paco (entrevistador) y Miguel (entrevistado), la historia de un miliciano republicano anónimo que se une a la causa antifascista, primero en España y luego como parte del bando de los aliados contra Hitler y los aliados de la Alemania nazi. (Viñeta 15)

Lo narrado por Miguel nos permite recordar a quienes creyeron y lucharon por ideas nobles, a quienes sufrieron en carne propia el conflicto bélico mundial más atroz de nuestra historia, a quienes olvidados en los libros de historia realizaron grandes proezas, a quienes pensaron que luego de la caída de los genocidas Hitler y Mussolini llegaría el turno de Franco y la liberación de España, algo que nunca ocurrió. ${ }^{47}$

47. Otra obra de Paco Roca acerca de la memoria es Arrugas, que nos cuenta la historia de Emilio, un adulto mayor que recluido en una residencia de ancianos se ve consumido por la degeneración senil y el Alzheimer. 
Viñeta 14. El arte de volar
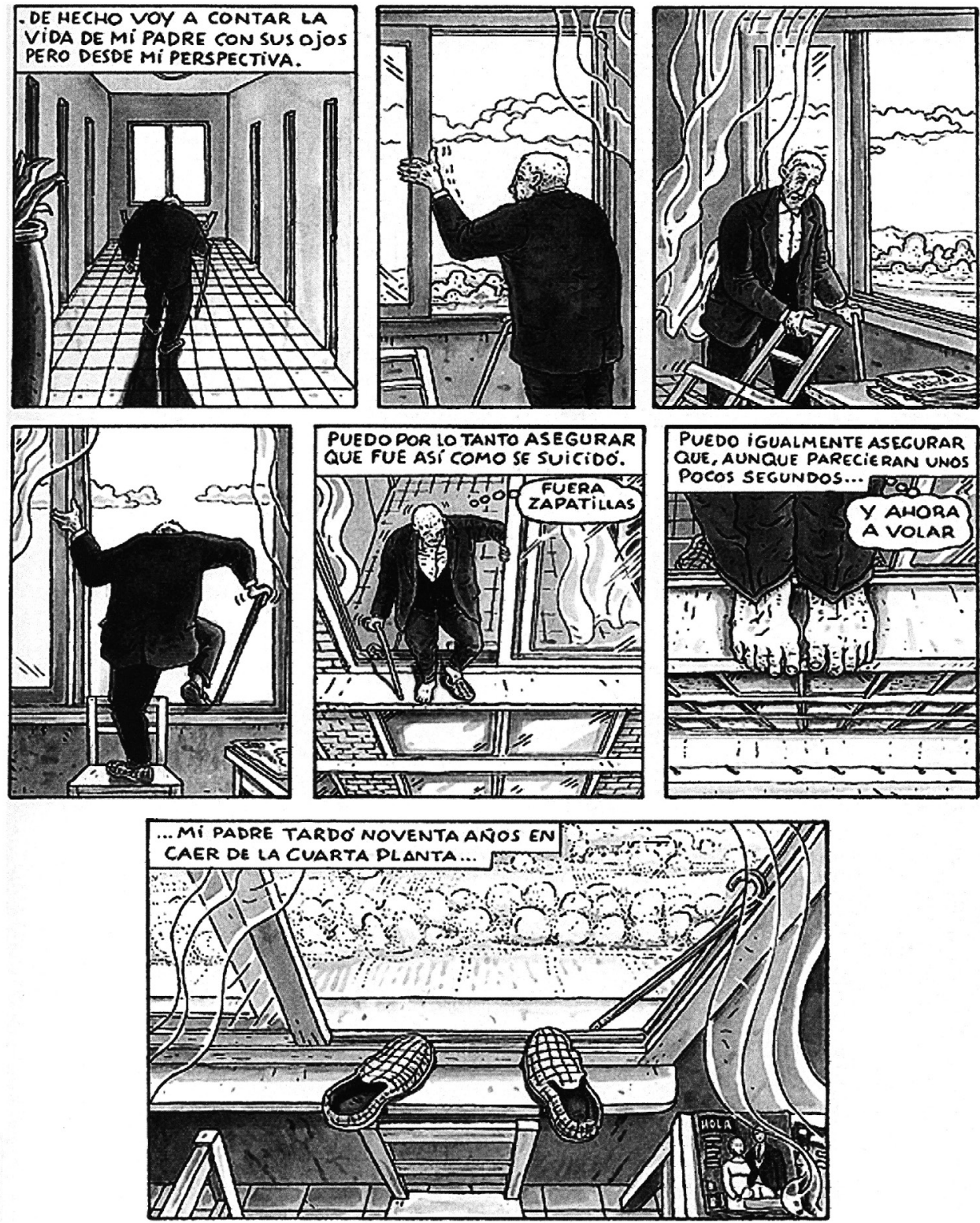

Fuente: Antonio Altarriba y Kim, El arte de volar (Alicante: De Ponent, 2009), 15. 
Viñeta 15. Los surcos del azar
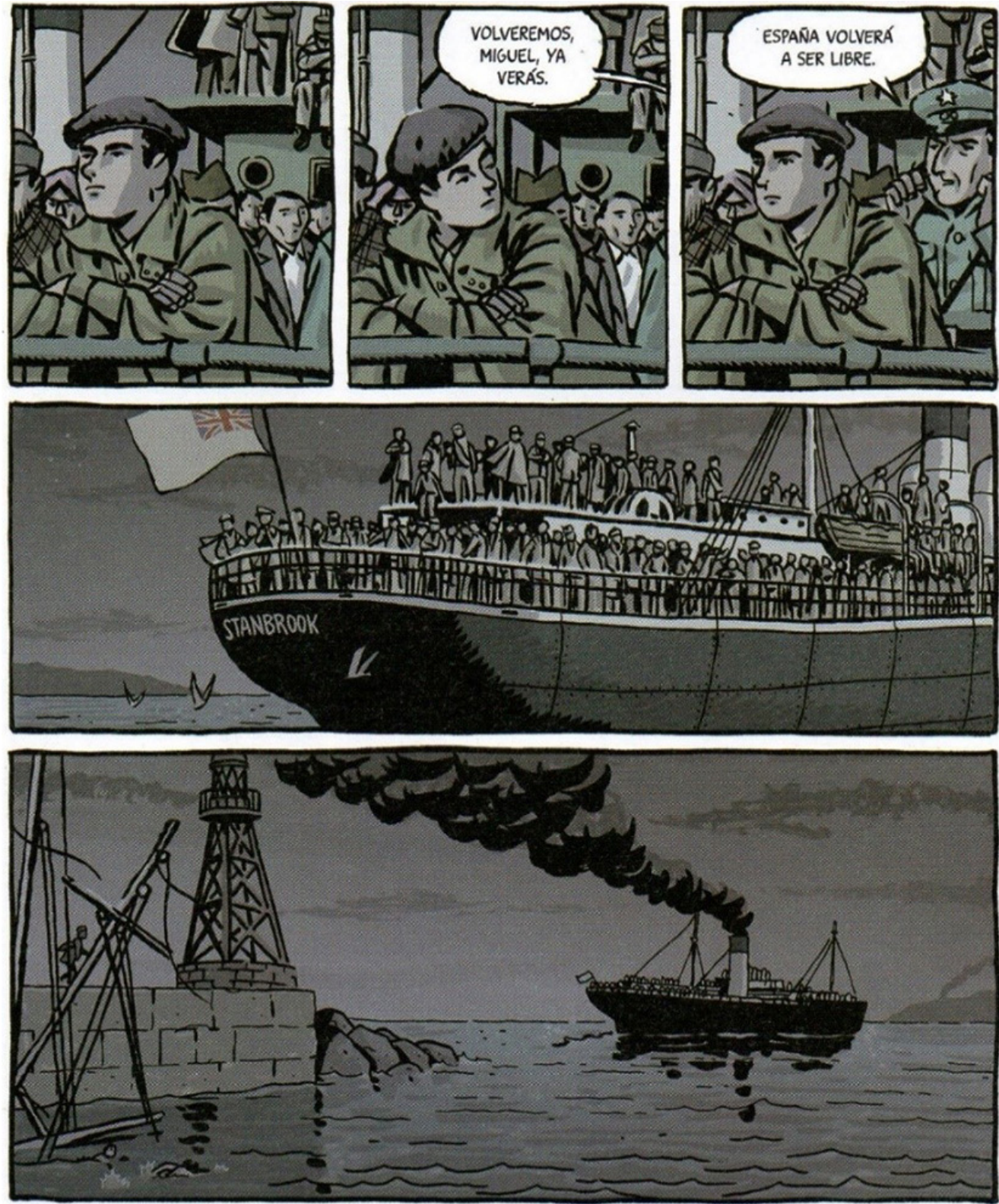

Fuente: Paco Roca, Los surcos del azar (Bilbao: Astiberri, 2013), 19. 
Finalizo la exploración del cómic y la memoria en España con Asylum, cómic de Javier Isusi. En esta ficción altamente realista se cuenta la historia de exilio de Marina, una mujer española y su familia que escapan de la Guerra Civil y la Segunda Guerra Mundial. Su historia de migración forzada, necesidad de refugio y asilo nos conduce por España, Francia y Venezuela en la búsqueda de un lugar seguro en el cual poder vivir. Asylum nos recuerda la crueldad de los conflictos armados, pero también nos recuerda la humanidad, el amor, la solidaridad y, por si fuera poco, lo cíclico de la historia. La narración de Marina es el hilo conductor de otras historias de exilio motivadas por la guerra, la violencia intrafamiliar, el matrimonio forzado, el femicidio, la homofobia, la represión y la persecución social y estatal. (Viñeta 16)

\section{Viñeta 16. Asylum}

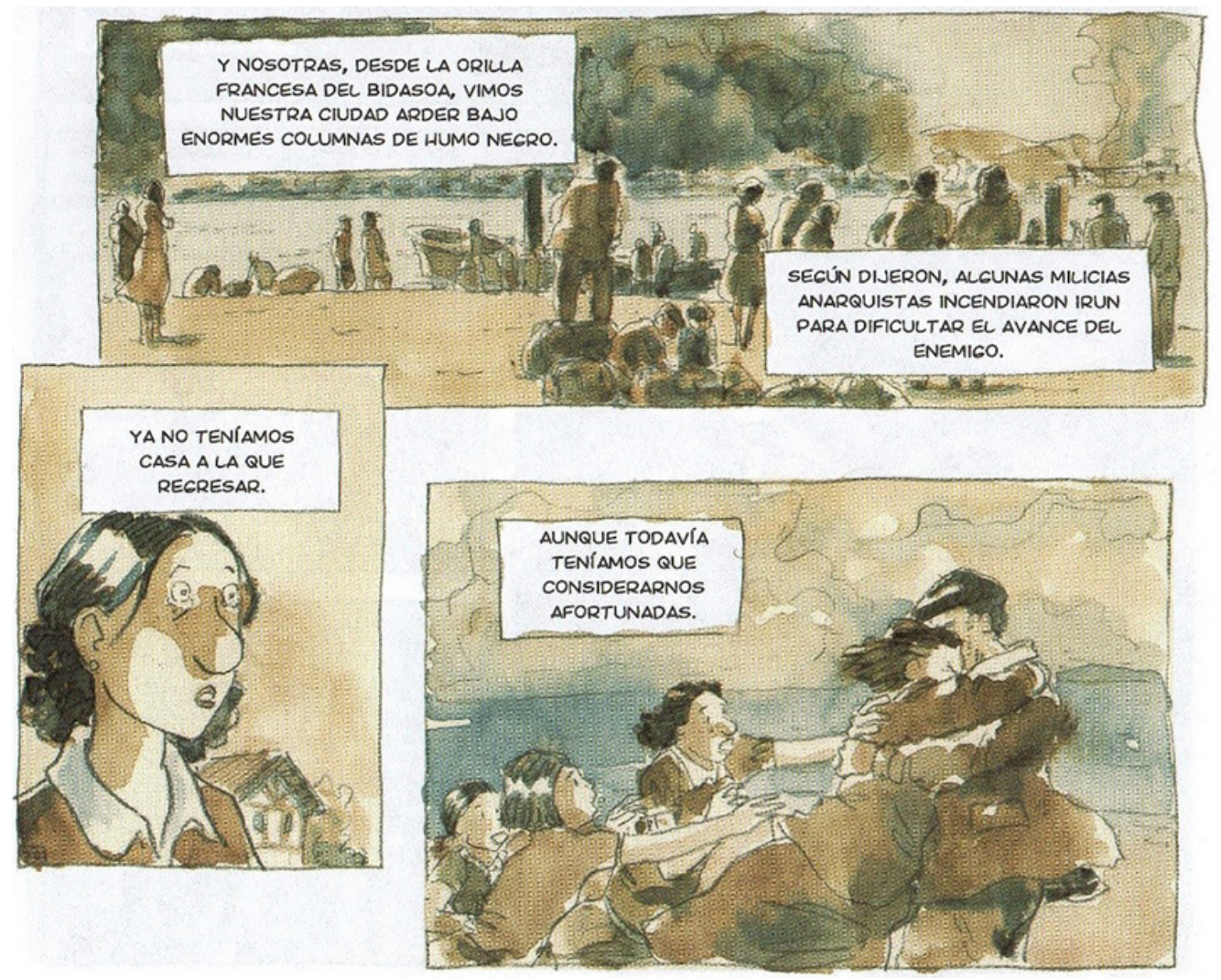

Fuente: Javier de Isusi, Asylum (Bilbao: Astiberri, 2017), 26. 


\section{CONCLUSIONES Y COMENTARIOS FINALES}

El cómic entendido como una auténtica manifestación cultural, expresión artística y medio de masas presenta importantes relaciones con otros conceptos, los cuales dan cuenta tanto de la relevancia del cómic como de los estudios interdisciplinarios que lo toman como objeto.

- Con la memoria como una herramienta narrativa de preservación de lo ocurrido y así también como una representación ética y estética que plantea lecturas alternativas a la historia y verdades oficiales dirigidas a la construcción de nuevas memorias. Es así que la relación entre cómic y memoria adquiere notable importancia en Iberoamérica como mecanismo individual y social de resistencia y reivindicación.

- Con los derechos humanos, esto al presentarse como un mecanismo que otorga voz a las víctimas y que sirve como un importante canal para su exigencia de los derechos a la verdad, justicia y reparación.

- Con la democracia, al ser un canal de difusión masiva que en un ejercicio de una ciudadanía activa, exige al Estado que asuma su responsabilidad dentro de los procesos masivos de violación de derechos humanos, ejerza sus obligaciones de recodar lo ocurrido, evitar el olvido, impedir la impunidad y garantizar la no repetición de lo ocurrido.

En general, este tipo de cómic tiene como características comunes, tanto en Latinoamérica como en España, el ser canales de expresión y difusión de historias personales con fuertes contenidos reivindicativos sociales. Así también, son narrativas fuertemente documentadas que reclaman expresa o tácitamente el cumplimiento de las obligaciones estatales de respeto y garantía de derechos. La principal diferencia entre estas obras no radica en su contenido o en su estilo, siendo bastante semejantes; sin embargo, en cuanto a su alcance y difusión la situación diverge. En España este cómic ha encontrado un público receptor masivo, un reconocimiento artístico y académico, lo cual ha redundado en la proliferación de obras, escenario distinto al latinoamericano, en el cual las iniciativas de este tipo de cómic son más bien escasas y con popularidad únicamente en un reducido grupo de lectores especializados.

Los estudios de este tipo de cómic a futuro plantean muchos retos sobre todo en Latinoamérica, región en que este tipo de estudios escasean y se centran en lo estilístico. Sería muy interesante explorar interdisciplinariamente las siguientes líneas de investigación: 1. cierta recopilación y clasificación de las obras repartidas en la región; 2. un estudio dividido en las características de sus géneros narrativos; 3. las particularidades de la industria del cómic y de los lectores; 4. el potencial del cómic 
como herramienta pedagógica y su impacto social; 5. el análisis del discurso de las principales obras en la región.

\section{BIBLIOGRAFÍA}

Altarriba, Antonio, y Kim. El arte de volar. Alicante: De Ponent, 2009.

Arias Rodríguez, Miguel Ángel, y Salvador López Arnal. "Entrevista a Miguel Ángel Rodríguez Arias: Desaparecidos del franquismo, trato inhumano a las familias e impunidad". Papeles de relaciones ecosociales y cambio global, n. ${ }^{\circ}$ 108, 2009: 133-43.

Arroyo, Francisco M., y Adolfo Usero. Dossiers. Madrid: De la Torre, 1980.

Asamblea General de las Naciones Unidas. Estatuto de Roma de la Corte Penal Internacional. 17 de julio de 1998.

- Principios y directrices básicos sobre el derecho de las víctimas de violaciones manifiestas de las normas internacionales de derechos humanos y de violaciones graves del derecho internacional humanitario a interponer recursos y obtener reparaciones. Resolución 60/147 aprobada el 16 de diciembre de 2005. 〈http://www.ohchr.org/SP/ ProfessionalInterest/Pages/RemedyAndReparation.aspx».

Asamblea Parlamentaria del Consejo de Europa. Need for International Condemnation of the Franco Regime. Recomendación 1736 de 17 de marzo de 2006. Disponible en inglés 〈https://search.coe.int/cm/Pages/result_details.aspx?ObjectID $=09000016805 \mathrm{c}$ $169 \mathrm{~d}\rangle$.

Barbero, Ruma, y Charo Borreguero. La Chelita. El Salvador 1992. Palma de Mallorca: Dolmen, 2013.

Bloom, Harold. Anatomía de la influencia. La literatura como modo de vida. Madrid: Taurus, 2011.

—. "Elegía al canon". En El canon literario, compilado por Enric Sullá, Madrid: ArcoLibros, 1998, 189-219.

Bórquez, Nestor. "La historieta de la memoria: la Guerra Civil y el franquismo en viñetas". Diablotexto Digital, n. ${ }^{\circ}$ 1, 2016: 29-55.

Bourriaud, Nicolas. Estética relacional. 2. ${ }^{a}$ ed. Buenos Aires: Adriana Hidalgo, 2008.

Caicedo Tapia, Danilo. “Cómic. Una herramienta metodológica para la educación en y para los derechos humanos" (tesis de fin del máster avanzado de derechos humanos). Madrid Getafe: UC3M, 2014. 〈https://e-archivo.uc3m.es/handle/10016/19892〉.

- Crimenes de lesa humanidad y violaciones de derechos. La actuación de la Comisión de la Verdad Ecuador. Quito: Universidad Andina Simón Bolívar, Sede Ecuador, 2014. 
Castilla del Pino, Carlos. "La forma moral de la memoria. A manera de prólogo". En El derecho a la memoria, dirigido por Felipe Gómez Isa. Bilbao: Alberdania, 2006, 15 20.

Comisión de la Verdad para El Salvador. Informe Comisión de la Verdad para El Salvador. De la Locura a la Esperanza: La guerra de los Doce Años en El Salvador, 1992-1993. 〈http:/www.derechoshumanos.net/lesahumanidad/informes/elsalvador/ informe-de-la-locura-a-la-esperanza.htm〉.

Comisión de la Verdad y Reconciliación del Perú. Hatun Willakuy (gran historia o relato) Versión abreviada del Informe Final de la Comisión de la Verdad y Reconciliación. Lima: CVR, 2008 [2004].

Comisión Nacional de Verdad y Reconciliación. Informe de la Comisión Nacional de Verdad y Reconciliación (Informe Rettig). Santiago de Chile: Corporación Nacional de Reparación y Reconciliación, 2007 [1991].

Comisión Nacional sobre la Desaparición de Personas (CONADEP) (Informe Sabato). Nunca Más. Edición del 30 aniversario del Golpe de Estado. Buenos Aires, Eudeba: 2011.

Comisión Nacional sobre Prisión Política y Tortura. Informe de la Comisión Nacional sobre Prisión Política y Tortura (Informe Valech). Santiago de Chile: Corporación Nacional de Reparación y Reconciliación, 2007 [2003].

Cossío, Jesús. Barbarie. Lima: Contracultura, 2010. 〈http://lum.cultura.pe/cdi/registrobibliografico/barbarie-comics-sobre-violencia-pol\%C3\%ADtica-en-elper\%C3\%BA-1985-1990〉.

De Isusi, Javier. Asylum. Bilbao: Astiberri, 2017.

ElDiario.es. "Un informe del Consejo de Europa abronca a España por abandonar a las víctimas del franquismo". 〈https:/www.eldiario.es/sociedad/Europa-Espana-abandono-victimas-desaparicion_0_495901430.html〉.

Elmundo.es. "Garzón recibe más de 140.000 nombres de desaparecidos en la Guerra Civil y la dictadura". 〈http://www.elmundo.es/elmundo/2008/09/22/espana/1222093274. html.

ElPeriodico.com. "La Guerra Civil en 10 cómics”. 〈https://www.elperiodico.com/es/ocioy-cultura/20160718/guerra-civil-diez-comic-5274920〉.

Escudero Alday, Rafael. "Memoria histórica e imperio de la ley: el poder judicial ante el derecho a la reparación de las víctimas del franquismo". Revista Derechos y Libertades. Revista de Filosofía del Derecho y Derechos Humanos, n. ${ }^{\circ} 38$, época II (enero 2018): 73-105.

Feierstein, Daniel. "Guerra, genocidio, violencia política y sistema concentracionario en América Latina". En Terrorismo de estado y genocidio en América Latina, editado por Daniel Feierstein, 9-32. Buenos Aires: Prometeo, 2009. 
- Memorias y representaciones. Sobre la elaboración del genocidio. Buenos Aires: Fondo de Cultura Económica, 2012.

Fronza, Emanuela. "La protección penal de la memoria: sobre el delito de negacionismo". En Memoria y derecho penal, editado por Pablo D. Eiroa y Juan M. Otero, 111-81 (Buenos Aires: Fabián J. Di Plácido, editor, 2007.

Giménez, Carlos. Barrio. Barcelona: Debols!1lo, 2011 [1978].

-.Paracuellos. 7. a ed. Barcelona: Debols!1lo, 2012 [1977].

Gómez Isa, Felipe. "El derecho de las víctimas a la reparación por violaciones graves y sistemáticas de los derechos humanos". En El derecho a la memoria, editado por Felipe Gómez Isa, 23-76. Bilbao: Alberdania, 2006.

González, Jorge, y Olivier Bras. ;Maldito Allende! Barcelona: ECC, 2017 [2015].

Grupo de Trabajo sobre las Desapariciones Forzadas o Involuntarias de las Naciones Unidas. Informe de Seguimiento de Recomendaciones Realizadas a España. Resolución A/HRC/36/39/Add.3, de 7 de septiembre de 2017. 〈https://documents-dds-ny.un.org/ doc/UNDOC/GEN/G17/260/51/PDF/G1726051.pdf?OpenElement〉.

Jelin, Elizabeth. Los derechos humanos y la memoria de la violencia política y la represión: la construcción de un campo nuevo en las ciencias sociales (Cuadernos del IDES, vol. 2). Buenos Aires: Instituto de Desarrollo Económico y Social, 2003.

Jiménez, Miguel, José Luis Jiménez y Andrés Cruz. Los Once. Bogotá: Laguna, 2014.

Matly, Michel. "El cómic español y la Guerra Civil: transición y primera década de democracia. 1976-1992”. En Tebeosfera, 2. época, n. ${ }^{\circ}$ 12, 2014. 〈http://www.tebeosfera.com/obras/documentos/el_comic_espanol_y_la_guerra_civil_transicion_y_primera_decada_de_democracia_-_1976-1992.html〉.

Merino, Ana. El cómic hispánico. Madrid: Cátedra, 2003.

Murillo, Luis, y Justo Jimeno. 17 días de julio. Madrid: De la Torre, 1982.

Oesterheld, Héctor Germán, y Francisco Solano López. El eternauta. Primera parte. Barcelona: RM, 2013 [1957].

-.El eternauta. Segunda parte. Barcelona: Norma, 2011 [1976].

Prado, Miguelanxo. Ardalén. 3. a ed. Barcelona: Norma, 2012.

Preston, Paul, y José Pablo García. La Guerra Civil Española. Barcelona: Debate, 2016.

Radio Recuperando Memoria. "Desmontando las cifras de la Fundación Francisco Franco sobre la represión franquista". Audio y texto disponibles en «https://radiorecuperandomemoria.com/2016/11/22/desmontando-las-cifras-de-la-fundacion-francisco-francosobre-la-represion-franquista/s.

Ramírez, Gloria. "La educación superior en derechos humanos y el papel de la pedagogía de la memoria". En Pedagogía de la memoria. Desafio para la educación en derechos humanos. Santiago de Chile: Heinrich Böll Stiftung Cono Sur, 2010, 33-49. 
Real Academia Española (RAE). Diccionario de la lengua española. 23. ${ }^{a}$ ed. 〈http://lema. rae.es $/ \mathrm{drae} 2001 / \mathrm{srv} / \mathrm{search}$ ?id=8WXeqLsI3DXX255eEiUg .

Reyes, Carlos, y Rodrigo Elgueta. Los años de Allende. Santiago de Chile: Hueders, 2015.

Rincón, Tatiana. "La decisión judicial en la construcción de la memoria colectiva". En Memoria y derecho penal, editado por Pablo D. Eiroa y Juan M. Otero, 215-37. Buenos Aires: Fabián J. Di Plácido editor, 2007.

Roca, Paco. Los surcos del azar. Bilbao: Astiberri, 2013.

Rossell, Luis, Alfredo Villar y Jesús Cossío. Rupay. Lima: Contracultura, 2008. «http:// lum.cultura.pe/cdi/registrobibliografico/rupay-historias-gr\%C $3 \%$ A1ficas-de-la-violencia-en-el-per\%C3\%BA-1980-1984〉. 